\title{
Profile of Precision Farming Vegetable Beneficiaries in Ongur Sub-Basin under Tn-Iamwarm Project
}

\author{
P.Sindhuja ${ }^{1}$, Dr.M.Shanthasheela ${ }^{2}$ \\ Ph.D Research Scholar ${ }^{1},{ }^{2}$ Assistant professor (Agricultural extension) \\ Department of Agricultural Extension and Rural Sociology, Tamil Nadu Agricultural University, Coimbatore
}

\begin{abstract}
Precision Farming technologies can enhance the productivity in agriculture. It is an effective tool for conserving water resources and the research studies revealed that significant water saving ranged between 40 to 50 per cent by drip irrigation compared with surface irrigation, with increased yield as high as 100 per cent in some crops under specific locations. This study deals with the profile of precision farming vegetable beneficiaries in ongur sub-basin under Tn-Iamwarm Project. The study was conducted in the Ongur sub basin under TN-IAMWARM covers 28 villages in seven blocks within three districts such as Kancheepuram, Villupuram and Thiruvannamallai in Tamil Nadu. The farmers were cultivating Watermelon, Chillies, Brinjal, Bhendi, Bittergourd, Muskmelon, Moringa, Ridgegourd and Bottlegourd. It was selected based on the water availability for farming situation. A sample size of 174 farmers in this basin was fixed and selected through proportionate random sampling. The respondents were interviewed personally by a semi-structured and pre-tested interview schedule. The data thus collected were analyzed by using appropriate statistical tools. The main objective is to study the profile of precision farming vegetable beneficiaries in ongur sub-basin. As a result nearly majority $(89.65 \%)$ of the beneficiaries is found to be old aged, about 98.25 per cent of the respondents had farming experience of more than ten years, majority (75.86\%) fell under low crop diversification and more than half $(43.67 \%)$ of the respondents had medium level of exposure to agricultural messages, around fifty five per cent $(54.02 \%)$ of the respondents had high favourable attitude towards precision farming. Sixty two per cent had high scientific orientation, towards precision farming and majority $(62.06 \%)$ of them had high level of economic motivation towards precision farming.
\end{abstract}

\section{INTRODUCTION}

As per the project work implemented in Ongur Sub-basin, the study has been performed to analyze and understand the profile characteristics of precision farming vegetable beneficiaries in this basin. Over the last ten years Indian agriculture particularly Tamil Nadu agriculture has undergone considerable change in irrigation. Tamil Nadu farmers have faced challenges and opportunities with the existing climate conditions and introduction of precision farming techniques. The profile characteristics of these farmers involve a greater impact in adopting precision farming techniques and implement it in real-time. This study will give a clear picture about the farmer's background which in turn will help in giving appropriate policy implications based on derived conclusions.

\section{RESEARCH METHODOLOGY}

Kancheepuram, Villupuram and Thiruvannamalai Districts of Ogur sub-basin in Tamil Nadu were purposively selected for this study. Data collection was done with the use of a semi -structured and pre-tested interview schedule. The data were collected during the month of February 2015, by personally interviewing the respondents. Necessary effort was made to check and cross check the data collected from the respondents. The statistical tool used in this study was simple percentage analysis. Percentage analysis was used in descriptive analysis for making simple comparisons.

\section{FINDINGS AND DISCUSSION}

The findings emerged out of the present investigation are highlighted and elaborated along with relevant discussion under the Profile characteristics of precision farming vegetable beneficiaries in ongur sub-basin in Tamilnadu. 
Dr.M.Shanthasheela \& P.Sindhuja "Profile of Precision Farming Vegetable Beneficiaries in Ongur SubBasin under Tn-Iamwarm Project "

\section{Profile Characteristics of Precision Farming Vegetable Beneficiaries in Ongur Sub-Basin}

Table1. Age Profile of Precision farming beneficiaries $(n=174)$

\begin{tabular}{|l|l|l|l|}
\hline Sl. No. & Category & No. & \% \\
\hline 1 & Young(Upto 35 years) & 4 & 2.30 \\
\hline 2 & Middle(35 to 45 years) & 14 & 8.05 \\
\hline 3 & Old(More than 45 years) & 156 & 89.65 \\
\hline & Total & $\mathbf{1 7 4}$ & $\mathbf{1 0 0}$ \\
\hline
\end{tabular}

Table 1 reveals that majority $(89.5 \%)$ of the farmers who adopted precision farming techniques were more than 45 years old. This in turn implies that the people under old age category are more adaptive to precision farming in real time than other category of ages. The adoption of alternate irrigation is to overcome the failed rainfall and dry land conditions which the people of old age are ready to oft for precision farming.

Table2. Educational status of the precision farming beneficiaries $(n=174)$

\begin{tabular}{|l|l|l|l|}
\hline Sl. No. & Category & No. & \% \\
\hline 1 & Illiterate & 22 & 12.64 \\
\hline 2 & Functionally literate & 41 & 23.56 \\
\hline 3 & Primary education & 3 & 1.74 \\
\hline 4 & Middle education & 103 & 59.20 \\
\hline 5 & Higher secondary education & 1 & 0.56 \\
\hline 6 & Diploma & 2 & 1.15 \\
\hline 7 & Under graduate & 2 & 1.15 \\
\hline & Total & $\mathbf{1 7 4}$ & $\mathbf{1 0 0}$ \\
\hline
\end{tabular}

Table 2 revealed that more than half $(59.20 \%)$ of the precision farming beneficiaries had middle school education followed by $(23.56 \%)$ are functionally literate and 12.64 per cent are illiterate and 1.74 per cent had primary school education, 1.15 per cent each had degree and diploma education, rest 0.56 per cent had secondary education. Majority of the respondents had middle education; it might be due to their poor economic status and lack in reach of educational institutes.

Table3. Distribution of Precision farming beneficiaries according to Occupational Status $(n=174)$

\begin{tabular}{|l|l|l|l|}
\hline Sl.No. & Category & No. & \% \\
\hline 1 & Farming alone & 168 & 96.55 \\
\hline 2 & Farming + wage earner & 4 & 2.30 \\
\hline 3 & Farming +Service & 2 & 1.15 \\
\hline & Total & $\mathbf{1 7 4}$ & $\mathbf{1 0 0}$ \\
\hline
\end{tabular}

Table 3 revealed that almost majority (96.55\%) of the beneficiaries had agriculture as their main occupation, followed by wage earner $(2.30 \%)$ and the remaining 1.15 per cent had agriculture and service as subsidiary occupation. This directly implies those who have farming as main occupation are more adapted to precision farming than the other ones. The other categories may have meager number because according to them farming is a secondary occupation which in turn the might be reluctant to invest and involve precision technologies in their fields.

Table4. Distribution of Precision farming beneficiaries according to Annual Income $(n=174)$

\begin{tabular}{|l|l|l|l|}
\hline Sl. No. & Category & No. & \% \\
\hline 1 & Rs. 50,001 - Rs. 1,00,000 & 64 & 36.78 \\
\hline 2 & Rs. 1,00,001 - Rs. 2,00,000 & 51 & 56.32 \\
\hline 3 & Above Rs. 2,00,000 & 10 & 6.90 \\
\hline & Total & $\mathbf{1 7 4}$ & $\mathbf{1 0 0}$ \\
\hline
\end{tabular}

The results in Table 4 indicated that more than half $(56.32 \%)$ of the beneficiaries had earned Rs. 1,00,001 - 2,00,000 followed by 36.78 per cent who had earned Rs. 50.001-1,00,000 and remaining 6.90 per cent had earned above Rs. 2,00,000. This indicates that marginal farmers of income below 1 lakh per annum are more inclined towards the adoption of precision farming techniques than the medium farmers earning above 2 lakh per annum.

Table5. Distribution of precision farming beneficairies according to Area under Precision Farming $(n=174)$

\begin{tabular}{|l|l|l|l|}
\hline Sl.No. & Category & No. & $\%$ \\
\hline 1 & Small (1 ac) & 66 & 37.94 \\
\hline 2 & Medium (1-2 ac) & 24 & 13.79 \\
\hline
\end{tabular}


Dr.M.Shanthasheela \& P.Sindhuja "Profile of Precision Farming Vegetable Beneficiaries in Ongur SubBasin under Tn-Iamwarm Project "6

\begin{tabular}{|l|l|l|l|}
\hline 3 & Large $(>3 \mathrm{ac})$ & 84 & 48.27 \\
\hline & Total & $\mathbf{1 7 4}$ & $\mathbf{1 0 0}$ \\
\hline
\end{tabular}

From Table 5 it is found that nearly half of the respondents $(48.27 \%)$ possessed more than three acre followed by 37.94 per cent with one acre and remaining 13.79 per cent with two acre area under precision farming.

From the above table we could conclude that high area results in high income (Rs. 1,00,001 $2,00,000)$ and also the farmers were ready to adopt new technology. This might be the possible reason that more than half of the respondents $(48.27 \%)$ possessed more than three acres of precision farming cultivation.

Table6. Distribution of Precision farming beneficiaries according to Farming Experience $(n=174)$

\begin{tabular}{|l|l|l|l|}
\hline Sl.No. & Category & No. & \% \\
\hline 1 & Upto 5 years & 1 & 0.58 \\
\hline 2 & $5-10$ years & 2 & 1.17 \\
\hline 3 & $>10$ Years & 168 & 98.25 \\
\hline & Total & $\mathbf{1 7 4}$ & $\mathbf{1 0 0}$ \\
\hline
\end{tabular}

Table 6 indicated that majority of the respondents $(98.25 \%)$ had more than ten years of farming experience followed by 1.17 per cent of the respondents with five to ten years of farming experience. The remaining 0.58 per cent of them had upto five years of farming experience.

As majority of the respondents had agriculture as their primary occupation $(90.50 \%)$ and majority of farmers are old aged $(89.65 \%)$ this might be the possible reason for more years of farming experience.

Table7. Distribution of Respondents according to Experience in Precision Farming $(n=174)$

\begin{tabular}{|l|l|l|l|}
\hline Sl.No. & Year of experience & No. & $\%$ \\
\hline 1 & Upto 1 year & 138 & 79.32 \\
\hline 2 & 1-2 years & 14 & 8.04 \\
\hline 3 & 2-3 years & 14 & 8.04 \\
\hline 4 & 3-4 years & 8 & 4.60 \\
\hline & Total & $\mathbf{1 7 4}$ & $\mathbf{1 0 0}$ \\
\hline
\end{tabular}

Table 7 indicated that majority $(79.2 \%)$ of the beneficiaries followed precision farming in the year 2013-2014 followed by 8.04 per cent each at 2011-2012 and 2012 -2013 and remaining 4.60 per cent in 2010-2011years. Ongur sub-basin TN-IAMWARM project is implemented from 2010 at third phase. The project duration was five years. So majority of farmer were just aware and started to adopt precision farming technology and also maximum number (138 no's) of beneficiaries practiced precision farming at 2013-2014 year. This might be the possible reason for maximum adoption in 2013-2014.

Table8. Distribution of Precision farming beneficiaries according to Crop Diversification $(n=174)$

\begin{tabular}{|l|l|l|l|}
\hline Sl.No & Category & No. & \% \\
\hline 1 & Low(Below 0.45) & 132 & 75.86 \\
\hline 2 & Medium(0.45-0.65) & 13 & 7.48 \\
\hline 3 & High(Above 0.65) & 29 & 16.66 \\
\hline & Total & $\mathbf{1 7 4}$ & $\mathbf{1 0 0}$ \\
\hline
\end{tabular}

From Table 8, it could be inferred that majority (75.86\%) fell under low crop diversification followed (16.66\%) by high crop diversification and rest $(7.48 \%)$ with medium crop diversification. Majority fell under low crop diversification because precision farming vegetable beneficiaries saw high income on watermelon compared to chilies, gourds, brinjal and bhendi. Farmers cultivated watermelon atleast once in their cropping cycle or in small conventional area with other vegetables, mainly because of its duration and income. This might be the reason for low crop diversification.

Table9. Distribution of Precision farming beneficiaries according to Exposure of Agricultural Messages

\begin{tabular}{|c|c|c|c|c|c|c|c|c|c|}
\hline \multirow{3}{*}{$\begin{array}{l}\text { Sl. } \\
\text { No }\end{array}$} & \multirow{3}{*}{ Nature of Exposure } & \multicolumn{6}{|c|}{ Frequency of Exposure } & \multicolumn{2}{|c|}{ Total } \\
\hline & & \multicolumn{2}{|c|}{ Regularly (3) } & \multicolumn{2}{|c|}{ Occasionally(2) } & \multicolumn{2}{|c|}{ Never (1) } & \multirow{2}{*}{ No. } & \multirow{2}{*}{$\%$} \\
\hline & & No. & $\%$ & No. & $\%$ & No. & $\%$ & & \\
\hline 1. & $\begin{array}{l}\text { Listening to Agricultural information } \\
\text { in Radio }\end{array}$ & - & - & 57 & 32.18 & 118 & 67.82 & 174 & 100 \\
\hline 2. & $\begin{array}{l}\text { Reading Agricultural Newspapers, } \\
\text { Agrl. Magazines, booklets, folders, etc. }\end{array}$ & 30 & 17.24 & 45 & 25.86 & 99 & 56.90 & 174 & 100 \\
\hline
\end{tabular}


Dr.M.Shanthasheela \& P.Sindhuja "Profile of Precision Farming Vegetable Beneficiaries in Ongur SubBasin under Tn-Iamwarm Project "6

\begin{tabular}{|l|l|l|l|l|l|l|l|l|l|}
\hline 3. & Visiting Agrl. Exhibitions & - & - & 3 & 1.72 & 171 & 98.28 & 174 & 100 \\
\hline 4. & $\begin{array}{l}\text { Participating in Agrl. Campaigns/ } \\
\text { Trainings }\end{array}$ & - & - & 57 & 32.18 & 118 & 67.82 & 174 & 100 \\
\hline 5. & $\begin{array}{l}\text { Attending Agrl. demonstrations / Field } \\
\text { days }\end{array}$ & - & - & 49 & 28.16 & 125 & 71.84 & 174 & 100 \\
\hline 6. & Watching Agrl. programmes on TV & 90 & 51.72 & 28 & 16.09 & 56 & 32.19 & 174 & 100 \\
\hline 7. & $\begin{array}{l}\text { Learning through correspondence } \\
\text { courses offered by TNAU/ others }\end{array}$ & - & - & - & - & 174 & 100 & 174 & 100 \\
\hline
\end{tabular}

Table10. Distribution of Precision farming beneficiaries according overall Exposure to Agricultural Message $(n=174)$

\begin{tabular}{|l|l|l|l|}
\hline Sl. No. & Category & No. & \% \\
\hline 1 & Low & 61 & 35.05 \\
\hline 2 & Medium & 76 & 43.68 \\
\hline 3 & High & 37 & 21.27 \\
\hline & Total & $\mathbf{1 7 4}$ & $\mathbf{1 0 0}$ \\
\hline
\end{tabular}

From Table 9 it could be inferred that majority (51.72\%) of respondents regularly receiving agricultural news through television programmes such as Malarum bhoomi in Makkal T.V, Uzhavarkku uyirootu in Puthiya thalaimurai, Pon villayum bhoomi in Pothigai and few reading magazines such as Ullavarin Valarum Velanmai, followed by $(17.54 \%)$ reading news in newspaper such as Dhinamalar, Thinnatandhi and 32.18 per cent had exposure to training, agriculture campaigns and listening radio. cent per cent of respondent had no exposure to correspondence courses followed by $(98.28 \%)$ rare exposure to agricultural exhibition.

From Table 10 it could be inferred that nearly half (43.68\%) of the beneficiaries had medium level of exposure to agricultural messages, followed by 35.05 per cent had low level of exposure to agricultural messages and the rest $(21.27 \%)$ had high level of exposure to agricultural messages.

Table11. Distribution of Precision farming beneficiaries according to overall Contact with Extension and other Agencies $(n=174)$

\begin{tabular}{|l|l|l|l|}
\hline Sl. No. & Category & No. & \% \\
\hline 1 & Low & 49 & 28.16 \\
\hline 2 & Medium & 48 & 27.59 \\
\hline 3 & High & 77 & 44.25 \\
\hline & Total & $\mathbf{1 7 4}$ & $\mathbf{1 0 0}$ \\
\hline
\end{tabular}

From Table 11, it could be observed that 44.25 per cent beneficiaries had high level of contact with extension and other agencies, followed by 28.16 per cent had low level of contact with extension agency and the rest $(27.59 \%)$ had medium level of contact with extension and other agencies.

Table12. Distribution of Precision farming beneficiaries according to over all Social Participation $(n=174)$

\begin{tabular}{|l|l|l|l|}
\hline Sl.No & Category & No. & \% \\
\hline 1 & Low & 101 & 58.05 \\
\hline 2 & High & 73 & 41.95 \\
\hline & Total & $\mathbf{1 7 4}$ & $\mathbf{1 0 0}$ \\
\hline
\end{tabular}

Results in Table 12 showed that 58.05 per cent of the beneficiaries were found with low level of social participation and rest $(41.95 \%)$ had high level of social participation. Lack of participation in social organization might be the reason that beneficiaries are found with low level of social participation.

Table13. Distribution of Precision farming beneficiaries according to Attitude towards Precision Farming $\quad(n=$ 174)

\begin{tabular}{|l|l|l|l|}
\hline Sl.No & Category & No. & \% \\
\hline 1 & Less favorable & 53 & 30.46 \\
\hline 2 & Favourable & 27 & 15.52 \\
\hline 3 & Highly favorable & 94 & 54.02 \\
\hline & Total & $\mathbf{1 7 4}$ & $\mathbf{1 0 0}$ \\
\hline
\end{tabular}

Table 13 revealed that more than half $(54.02 \%)$ of the respondents had more favorable attitude towards precision farming followed by less favorable (30.46\%) and favorable (15.52\%) attitude. The more tangible impact created through precision farming by TN-IAMWARM Project made the vegetables beneficiaries to have more favorable attitude towards precision farming. 
Dr.M.Shanthasheela \& P.Sindhuja "Profile of Precision Farming Vegetable Beneficiaries in Ongur SubBasin under Tn-Iamwarm Project "

Table14. Distribution of Precision farming beneficiaries according to Scientific Orientation $(n=174)$

\begin{tabular}{|l|l|l|l|}
\hline Sl. No. & Category & No. & \% \\
\hline 1 & Low & 37 & 21.26 \\
\hline 2 & Medium & 28 & 16.09 \\
\hline 3 & High & 109 & 62.65 \\
\hline & Total & $\mathbf{1 7 4}$ & $\mathbf{1 0 0}$ \\
\hline
\end{tabular}

From Table 14 it could be inferred that 62.65 per cent had high scientific orientation, followed by $(21.26 \%)$ low scientific orientation and rest (16.09\%) had medium scientific orientation. Majority of the farmers believed that new method gave better results, experiences promote new farming methods, new learning worth effort and change in traditional method raise standard of living this might be the reason for high social motivation.

Table15. Distribution of Precision farming beneficiaries according to Economic Motivation $(n=174)$

\begin{tabular}{|l|l|l|l|}
\hline Sl.No & Category & No. & \% \\
\hline 1 & Low & 37 & 21.26 \\
\hline 2 & Medium & 29 & 16.68 \\
\hline 3 & High & 108 & 62.06 \\
\hline & Total & $\mathbf{1 7 4}$ & $\mathbf{1 0 0}$ \\
\hline
\end{tabular}

The above Table 15 revealed that 62.06 per cent had high level of economic motivation followed by low level $(21.26 \%)$ and 16.68 per cent of the respondents comes under medium level of economic motivation. The basic instinct of a farmer is to earn more income from their farming whatever may be the type of farming approach they follows. With the minimum assurance of getting positive return from precision farming the farmers had taken up this venture. This revenue generation characteristically motivated them to adopt precision farming.

\section{SUMMARY AND CONCLUSION}

In any extension study, it is inevitable to analyze the farmer's characteristics. This will give a clear picture about the farmer's background which in turn will help in giving appropriate policy implications based on derived conclusions. Precision farming techniques can improve the economic and environmental sustainability of crop production. The producer can apply production inputs in the precise location and quantity they are needed for maximum economic yield.

It would be appropriate to undertake impact studies, so as to assess the effectiveness of the interventions in terms of increasing the socio-economic status of the beneficiary farmers, besides proposing appropriate suggestions for effective implementation of the project.

The summary to the study of profile characteristics of precision farming beneficiaries are majority $(89.65 \%)$ of the beneficiaries is found to be old aged, majority of respondents had middle school education $(59.20 \%)$, almost majority $(96.55 \%)$ of the beneficiary respondents had agriculture as their main occupation. Majority of the respondents $(56.32 \%)$ came under higher income category of Rs.1,00,001- Rs.2,00,000. Nearly half of the respondents (48.27\%) possessed more than three acre followed by 37.94 per cent with one acre and remaining 13.79 per cent with two acre area under precision farming. About 98.25 per cent of the respondents had farming experience of more than ten years, majority (75.86\%) fell under low crop diversification and more than half $(43.67 \%)$ of the respondents had medium level of exposure to agricultural messages. It is also observed that nearly half $(44.25 \%)$ of the respondents had high level of contact with extension and other agencies, majority $(58.04 \%)$ of the beneficiary respondents are found with low level of social participation with around fifty five per cent $(54.02 \%)$ of the respondents had high favourable attitude towards precision farming. Sixty two per cent had high scientific orientation, towards precision farming and majority $(62.06 \%)$ of them had high level of economic motivation towards precision farming.

\section{REFERENCES}

[1] Anamika, M. 2010. Migration Behaviour of Dryland Farmers - An Ex Post Facto Study. Unpub. M.Sc. (Ag.) Thesis, AC\&RI, TNAU, Coimbatore.

[2] Arnholt, M., Batte, T., Prochaska, 2001. A Survey of Precision Farming Adopters in Central Ohio: Changing Farm Management Practices, AEDE-FR-0010-01, the Ohio University, USA. 
Dr.M.Shanthasheela \& P.Sindhuja "Profile of Precision Farming Vegetable Beneficiaries in Ongur SubBasin under Tn-Iamwarm Project "6

[3] Annual report 201-2014, Ministry of Agriculture, Government of India.

[4] Broke Anil and Copergaon. 2004. Drip irrigation. Agriculture Today, 7(10): 26-27.

[5] Daberkow, Stan, G., and W. D. Mc Bride, 1998. Adoption of Precision Agriculture Technologies by US Corn Producers, Precision Agriculture: Proceedings of the Fourth International Conference. p. 1821-1831.

[6] Darren Hudson and Diane Hite, 2001, Adoption of Precision Farming Technology in Missipisi: Results from Producer Survey. Research report-001, Missipisi State University.

[7] Elamurugannan, S. 2001. Economics of Mixed Farming in Rainfed Agriculture in Erode District of Tamil Nadu. Unpub. M.Sc. (Ag.) Thesis, AC\&RI, TNAU, Coimbatore.

[8] Flora, A. 1994. Farm Programmes in Radio and Television - A Comparative Analysis. Unpub. M.Sc. (Ag.) Thesis, TNAU, Coimbatore.

[9] Grisso, R. B. Alley, M. Phil McClellan, Dan Brann and Steve Donohue. 2002. Precision Farming: A Comprehensive Approach. Pub. 442-500. Virginia Cooperative Extension, Virginia State University, U.S.

[10] Harshal, E., Premod, Chaudhari, M., 2006, Precision Agriculture: A New Form of Agriculture to Maximize Crop Production and Minimize the Environmental Damage, Agricultural update, 1 (2): $24-25$.

[11] Indian Horticulture Database 2014, National Horticulture Board, Ministry of Agriculture, Government of India.

[12] Justin Arockiam, W. 2007. Agripreneurship under Tamil Nadu Precision Farming Project - A Case Study". Unpub. M.Sc. (Ag.) Thesis, AC\&RI, TNAU, Coimbatore.

[13] Lavanya, P. 2010. Diversification Patterns in Dryland Ecosystem - An Empirical Analysis. Unpub. M.Sc. (Ag.) Thesis, AC\&RI, TNAU, Coimbatore.

[14] Maheswari, 2008. Precision Farming Technology, Adoption Decisions and Productivity of Vegetables in Resource-Poor Environments. Unpub. M.Sc. (Ag.) Thesis, TNAU, Coimbatore.

[15] Manimekalai, V. 2011. Establishment of Hub and Spoke model for Innovative Farming Technology Dissemination in Tiruvannamalai district- An Action Research. Unpub. M.Sc. (Ag.) Thesis, AC\&RI, TNAU, Coimbatore.

[16] Mansingh, J. Paul, 1993. Construction and Standardization of Socio - Economic Status Scale. Unpub, M.Sc., (Ag) Thesis, AC\&RI, TNAU, Coimbatore.

[17] Meera, S.N., Jhamtani, A and D.U.M. Rao. 2004. Information and Communication Technology in Agricultural Development: A Comparative Analysis of Three Projects from India. Agricultural Research and Extension Network Paper ,135: 14.

[18] Nithya, S. 2014. TN-IAMWARM project: Socio - Economic Impact of Precision Farming in Sugarcane, Unpub.Ph.D. Thesis, AC\&RI, TNAU, Coimbatore.

[19] Ongur Sub-Basin Documentation Report 2010-2014, TNAU, Coimbatore.

[20] Padma, S. R. 2013. Perspectives of Stakeholders on Precision Farming, Unpub.Ph.D. Thesis, AC\&RI, TNAU, Coimbatore.

[21] Sathiya Chitradevi, M. 2006. Spread and Acceptance of Low Cost Technologies of Major Crops by Resource Poor Farmers. Unpub. M.Sc.(Ag.) Thesis, AC\&RI, TNAU, Coimbatore.

[22] Sathyasundaram, I. 2006. Micro irrigation and Drought Management. Kurukshetra, 54(8):32-34.

[23] Thangaraja, Karthikeyan, Asokhan and Rajasekar. 2008. Socioeconomic Analysis of Dry farming in Dindugul District of Tamil Nadu,Madras Agric. J., 95 (1-6): 120-128

[24] www.tniamwarm.gov.in

[25] http://agritech.tnau.ac.in/agriculture/ag ri_soilgroups.html

[26] www.nfsm.gov.in/Presentations/Rewards/TN.ppt 